\title{
ROLE OF CORTICOSTEROIDS IN REDUCTION OF POST-OPERATIVE OEDEMA IN CRANIOFACIOMAXILLARY SURGERY
}

\author{
Anil Kumar Malhari ${ }^{1}$,Ramesh Sharma², Vidya Rattan ${ }^{3}$ \\ ${ }^{1}$ Assistant Professor, Department of Plastic Surgery, Mahadevappa Rampure Medical College, Gulbarga. \\ 2 Professor and HOD, Department of Plastic Surgery, Post Graduate Institute of Medical Education and Research, Chandigarh. \\ ${ }^{3}$ Associate Professor, Unit of Oral \& Maxillofacial Surgery, Oral Health Sciences Centre, Post Graduate Institute of Medical Education \& \\ Research, Chandigarh.
}

\begin{abstract}
Postoperative oedema and ecchymosis are common complaints following facial plastic surgical procedures. The resulting oedema and ecchymosis is socially disturbing and sometimes frightening for the patient. Serious consequences of oedema include airway obstruction, conjunctival chemosis with possible transient loss of vision and pain. Perioperative administration of steroids has been used in Craniofaciomaxillary procedures with a belief that it reduces postoperative swelling and shortens time to recovery after surgery. Various perioperative regimens of systemic corticosteroid administration have been reported to result in a significant reduction in postoperative facial oedema following cranioplasty, orbital floor exploration, mandibular and maxillary osteotomy, facial plasty, hair transplant and rhinoplasty. A number of experimental animal studies have demonstrated decreased oedema in flap models or replants. However, several clinical studies evaluating the use of steroids perioperatively in a variety of orthognathic and facial surgical procedures have failed to provide concrete evidence for or against steroid usage. Proponents of steroid use (Nordstrom et al, Flood et al and Gurlek et al) claim, it decreases postoperative oedema, decreases ecchymosis, improves surgical outcome, reduces home convalescence, decreases hospital stay and causes euphoria. Opponents of steroid use (Munro et al, Rapaport et al, and Owsley et al) claim lack of evidence, serious complications like inhibition of Hypothalamic Pituitary-Adrenal axis, avascular necrosis of hip and humerus, alter blood sugar levels, increased risk of hypertension, increase in the incidence of wound infection and lack of cost effectiveness. A prospective double-blind study conducted to evaluate the role of Dexamethasone 8 mg intravenous administration and Triamcinolone $0.7 \mathrm{mg} / \mathrm{kg}$ administration at the end of procedure in reduction of postoperative facial oedema in Craniofaciomaxillary surgeries. Thirty-four consecutive patients were randomized to Dexamethasone, Triamcinolone administration and control group. Facial size was measured on POD1, POD2 and POD3. Facial oedema scores were derived from comparison of photographs on admission and $48 \mathrm{hrs}$. postoperatively. Findings were tabulated and statistically analysed. Following observations were noted. The duration of surgery and postoperative facial oedema did not correlate. We found that oedema was maximum in the periorbital region in all the three groups followed by oedema on forehead, malar and mandibular regions. We also observed that there was direct correlation between forehead and periorbital oedema. We observed that there was postoperative facial oedema on POD1, reached its peak on POD2 and then started declining within each group. The use of steroids either intravenous ( $8 \mathrm{mg}$ Dexamethasone) or local infiltration (Triamcinolone $0.7 \mathrm{mg} / \mathrm{kg}$ ) did not significantly reduce the postoperative facial oedema in our patient when compared to the control.
\end{abstract}

\section{KEYWORDS}

PGIMER-Post Graduate Institute of Medical Education and Research, Chandigarh, FS-Facial Size, FE-Facial Oedema, IMIntramuscular, IV-Intravenous, POD1-Post-Operative Day 1, POD2-Post-Operative Day 2, POD3-Post-Operative Day 3, DIFFSD1Difference in Facial Size on POD1 from Facial Size on Admission, DIFFSD2-Difference in Facial Size on POD2 from Facial Size on Admission, DIFFSD3-Difference in Facial Size on POD3 from Facial Size on Admission.

HOW TO CITE THIS ARTICLE: Malhari AK, Sharma R, Rattan V. Role of corticosteroids in reduction of post-operative oedema in craniofaciomaxillary surgery. J. Evolution Med. Dent. Sci. 2016;5(48):3090-3103, DOI: 10.14260/jemds/2016/719

\section{INTRODUCTION}

Postoperative oedema and ecchymosis are common complaints following facial plastic surgical procedures. The resulting oedema and ecchymosis is socially disturbing and sometimes frightening for the patient. Serious consequences of oedema include airway obstruction, conjunctival chemosis with possible transient loss of vision and pain.

Perioperative administration of steroids has been used in Craniofaciomaxillary procedures with the belief that it reduces post-operative swelling and shortens time to recovery after

Financial or Other, Competing Interest: None.

Submission 31-03-2016, Peer Review 24-05-2016,

Acceptance 30-05-2016, Published 16-06-2016.

Corresponding Author:

Dr. Anil Kumar Malhari,

Plot No. 13, Matru Chaya,

Om Nagar, Sedam Road,

Gulbarga-585105, Karnataka.

E-mail:dr.anilsm@gmail.com

DOI: $10.14260 /$ jemds/2016/719 surgery. Various perioperative regimens of systemic corticosteroid administration have been reported to result in a significant reduction in postoperative facial oedema following cranioplasty, orbital floor exploration, mandibular and maxillary osteotomy, facial plasty, hair transplant and rhinoplasty.

A survey of North American members of the American Society of Maxillofacial Surgeons was conducted to ascertain the prevalence of perioperative corticosteroid usage by surgeons performing craniomaxillofacial surgery (1999). ${ }^{1}$ Twenty-eight (46.7 percent) responders reported using shortterm, high-dose, perioperative corticosteroids to control postsurgical inflammation. Surgeons performing facial aesthetic surgery alone or in addition to craniomaxillofacial surgery were more likely to use steroids. A variety of steroid drugs and regimens were cited by steroid users. The most common reason for using steroids was to decrease oedema. Thirty-two (53.3 percent) responders reported that they were not using steroids. The most common reason for not using 
them was a lack of evidence to support their effectiveness. The majority of steroid user (78.3 percent) reported no complications. The most common complication encountered was euphoria (13.3 percent). No one reported the occurrence of avascular necrosis of the hip or humerus with the use of steroids. The most commonly used steroids reported were Dexamethasone and Methylprednisolone.

A number of experimental animal studies have demonstrated decreased oedema in flap models or replants. ${ }^{2,3,4}$ However, several clinical studies evaluating the use of steroids perioperatively in a variety of orthognathic and facial surgical procedures have failed to provide concrete evidence for or against steroid usage.

Proponents of steroid use (Nordstrom et $\mathrm{al}^{5}$, Flood et $\mathrm{al}^{6}$ and Gurlek et $\mathrm{al}^{7}$ ) claim, it decreases postoperative oedema, decreases ecchymosis, improves surgical outcome, reduces home convalescence, decreases hospital stay and causes euphoria. Opponents of steroid use (Munro et al, ${ }^{8}$ Rapaport et $\mathrm{al}^{9}$ and Owsley et $\mathrm{al}^{10}$ ) claim lack of evidence, serious complications like inhibition of Hypothalamic-PituitaryAdrenal axis, avascular necrosis of hip and humerus, alter blood sugar levels, increase risk of hypertension, increase in the incidence of wound infection, and lack of cost effectiveness.

The use of steroids in reducing postoperative facial oedema is highly controversial. Therefore, a prospective randomized study was designed to evaluate the role of intravenous Dexamethasone and local infiltration of Triamcinolone in reducing postoperative facial oedema in various craniofaciomaxillary procedures.

\section{REVIEW OF LITERATURE}

Schaberg et al (1984).11 studied the effect of Methylprednisolone on swelling after orthognathic surgery. A reduction in facial oedema was clearly demonstrated in osteotomised patients who received the steroid perioperatively. These authors showed that in various facial osteotomies, Methylprednisolone reduced facial oedema by 38 to 61 percent at 24 hours and by 10 to 45 percent at 72 hours postoperatively.

Habal (1985). ${ }^{12}$ observed 158 patients undergoing various facial surgical procedures who received $1 \mathrm{~g}$ of Methylprednisolone intravenously at the conclusion of the procedure. He concluded that the degree of facial oedema was reduced, that the patients required less analgesia and that no adverse effects of the medication occurred. However, he did not use a control group for comparison.

Munro et al (1986). ${ }^{8}$ studied thirty-six paediatric patients (Age range, 6 to 18 years; mean, 15 years) undergoing mandibular and/or maxillary osteotomies. Patients were randomized in a double blind study to determine objectively therapeutic value of steroids. Dexamethasone or a saline placebo was administered immediately preoperatively $(0.5$ $\mathrm{mg} / \mathrm{kg}$ ) and for 48 hours postoperatively $(0.25 \mathrm{mg} / \mathrm{kg} /$ day $)$. Standardized surgical techniques and fluid administration were used. Photographs of the patient taken on admission and 24 hours postoperatively compared by three independent observers familiar with maxillofacial surgery to rate facial swelling. Mean intubation period, time until oral intake was satisfactory and facial swelling ratings were compared between the two groups. The result seemed better for patients receiving steroids, but the difference was not significant. This study did not confirm the subjective belief of many surgeons that steroid administration reduces facial swelling after maxillofacial surgery.

Nordstrom (1987). ${ }^{5}$ studied the effect of corticosteroid on postoperative oedema by administration of $80 \mathrm{mg}$ of Methylprednisolone acetate (DM) given IM preoperatively. Forty-four patients undergoing 88 punch hair grafting were studied. The procedure was exactly the same in all patients. All patients went through two similar operations, one with preoperative Methylprednisolone and another without. The frequency of oedema dropped from 88.6 to 61.4 percent when Methylprednisolone was used. The difference was statistically significant. In addition, the duration of oedema dropped from 3.54 to 2.07 days when Methylprednisolone was used and the degree of severity of oedema was less when Methylprednisolone was used.

The reduction of oedema in craniomaxillofacial surgery may be beneficial in improving the immediate postoperative appearance of patients resulting in reduction of their convalescence. ${ }^{7}$ Furthermore, oedema reduction may be beneficial in preventing more serious oedema related complications such as upper airway obstruction, chemosis and pain.

Corticosteroid minimizes swelling by increasing antiinflammatory proteins (Annexin I, Mitogen-activated protein kinase phosphatase) and by down regulating proinflammatory cytokines (Tumour necrosis factor alpha and Interleukin 8). ${ }^{13,14}$ It is also possible that earlier discharge from the hospital could be related to the other beneficial actions of perioperative systemic corticosteroid, such as reduced postoperative nausea and vomiting. ${ }^{15,16,17,18}$ (by stimulating release of endorphins, antagonizing prostaglandins and depleting tryptophan). ${ }^{19,20}$ and reduced postoperative pain (by inhibiting the cyclooxygenase and lipoxygenase inflammatory pathways). ${ }^{21}$

Griffies et al (1989).22 used a single dose of Dexamethasone preoperatively in Rhinoplasty and studied its effect at only the first postoperative day. They reported that Dexamethasone was beneficial in decreasing oedema and ecchymosis on the first operative day. Griffies et al also reported their observations on the decrease in bleeding with steroids. They speculated that this decrease of intraoperative bleeding might be due to an interaction between the steroids and epinephrine.

Weber and Griffin (1994).23 studied the efficacy of Dexamethasone in reducing postoperative oedema after bilateral mandibular sagittal osteotomy and demonstrated significantly less postoperative oedema on postoperative day 1 alone.

Rapport et al (1995)..$^{9}$ performed a randomized, doubleblind study. Fifty consecutive facial plasty patients of one surgeon were randomized to steroid and no steroid groups. Steroid group patients received betamethasone $6 \mathrm{mg}$ IM preoperatively. Postoperative scoring of swelling was performed at approximately days 5 and 9 by a single observer. There were no significant differences between the two groups at either postoperative interval or in the rate of improvement. Subgroups of patients who underwent additional procedures also showed no significant differences. They were not able to demonstrate any statistically significant difference in swelling after facial plasty with this steroid regimen

Owsley et al (1996). ${ }^{10}$ conducted a prospective, doubleblinded study of 30 consecutive face lift patients to determine 
if the administration of corticosteroid medication would reduce postoperative facial oedema. Half the patients received steroid medications in a random fashion. Three independent plastic surgeons who were blinded to the study rated facial swelling by comparing preoperative and postoperative photographs using a scale of 1 to 4 . The data were tabulated and subjected to statistical analysis. There were no significant differences in facial swelling between the steroid treated group and the untreated patients on any occasion.

Flood et al (1999). ${ }^{6}$ conducted a prospective, randomized, double-blind trial; 20 patients who require orbital floor exploration after injuries selected. Patients were given Methylprednisolone $250 \mathrm{mg}$ (or placebo identically packaged) at induction of anaesthesia with a further three doses at 6 hourly intervals postoperatively. Differences in interpalpebral width before and after operation measured. Those given steroids had a significantly increased interpalpebral width compared with placebo postoperatively. He concluded that short courses of steroids therapy should be considered in orbital surgery for appropriate patients. There is an advantage in being able to assess the globe postoperatively.

To examine the effects of single dose Dexamethasone use on oedema, ecchymosis and intraoperative bleeding in rhinoplasty, a double-blind, randomized trial with placebo control was planned by Kara et al (1999). ${ }^{24}$ A total of 55 consecutive patients were included in the study. The Dexamethasone $(10 \mathrm{mg}$ ) was given intravenously just before surgery or at the end of surgery. In the placebo group, patients received saline preoperatively or postoperatively. Intraoperative blood loss was recorded for each patient. Postoperative scoring of eyelid swelling and ecchymosis was begun after approximately 24 hours and lasted into postoperative day 9 . Only for the first 2 days was the difference between steroid groups (Preoperative and postoperative) and the placebo group statistically significant for a decrease in eyelid oedema. Use of single dose Dexamethasone (Either preoperatively or postoperatively) in rhinoplasty had a significant effect in decreasing upper and lower eyelid oedema and upper eyelid ecchymosis for the first 2 days when compared with a placebo group. However, the effect of Dexamethasone was lost after the first 2 days and its use did not shorten the recovery period. In cosmetic surgery, it is important that patients experience the least amount of discomfort and anxiety possible after the surgical procedures. Attitudes of patients in the postoperative recovery period will be just as important as the surgical results. Therefore, lower levels of oedema and ecchymosis, even for just the first few postoperative days is a great benefit for the patient.

Neil-Dwyer et al (2001). ${ }^{25}$ conducted a study with preoperative tumescent infiltration using $7 \mathrm{~mL} / \mathrm{kg}$ of a solution consisting of $0.1 \mathrm{mg} / \mathrm{mL}$ Triamcinolone acetate, $0.0125 \%$ Bupivacaine, $0.025 \%$ Lignocaine, 3 units $/ \mathrm{mL}$ Hyaluronidase and 1:10,00,000 adrenaline in Hartmann's solution. A retrospective case controlled study of patients undergoing standard fronto-orbital remodelling for simple craniosynostosis $(n=20)$ was done. Eye closure (i.e. inability to open the eyes) was used as a marker for severe facial swelling. Patients receiving the tumescent infiltration demonstrated significantly less eye closure, implying that the tumescent infiltration had a significant effect on facial swelling. The avoidance of eye closure allowed more effective monitoring for neurological and ophthalmological complications, which is a significant clinical benefit. The infiltration solution has the advantage of a lower corticosteroid dose than previously reported Dexamethasone based perioperative regimens, thereby minimising any unwanted metabolic effects. The technique was advocated for the reduction of postoperative facial swelling in craniomaxillofacial surgical patients.

Eskal Kargi et al (2003). ${ }^{26}$ in a double-blind, randomized study determined the efficacy of Dexamethasone in decreasing periorbital oedema and ecchymosis after rhinoplasty and demonstrated a significant reduction in oedema in the early postoperative period. Sixty rhinoplasty patients undergoing hump resection and lateral osteotomy were included in the study and were divided into 6 groups: group 1 , single dose of $8 \mathrm{mg}$ IV Dexamethasone 1 hour before the operation; group 2, single dose of $8 \mathrm{mg}$ IV Dexamethasone at the beginning of the operation; group 3, 3 doses of $8 \mathrm{mg}$ IV Dexamethasone 1 hour before the operation and 24 and 48 hours after the operation; group 4, 3 doses of $8 \mathrm{mg}$ IV Dexamethasone at the beginning of the operation and 24 and 48 hours after the operation; group 5, 3 doses of $8 \mathrm{mg}$ IV Dexamethasone immediately after the operation, and 24 and 48 hours after the operation; group 6, control, no Dexamethasone administration before or after the operation. Intraoperative blood loss was recorded for each patient. Patients were evaluated at 24 hours and days 2, 5, 7 and 10. For the postoperative evaluation of periorbital ecchymosis and oedema, a scale of 0 to 4 points was used. There was no significant difference between groups in terms of bleeding. In the groups using steroid before osteotomy, oedema and ecchymosis were significantly lower during the first 2 days compared with the control group. No significant difference was seen between groups 1 and 2 . When patients were evaluated on day 5, oedema and ecchymosis were significantly lower in groups 3 and 4 compared with other groups, but there was no difference between them. Group 5 had a significantly higher level of oedema and ecchymosis compared with groups 1 through 4 at 24 hours and at days 2, 5 and 7. There was no significant difference between groups on day 10. In conclusion if the first dose was given before osteotomy, triple dose steroid application was the best for decreasing postoperative oedema and ecchymosis. None of the patients had any complications related to the use of Dexamethasone.

Gurlek et al (2006). ${ }^{27}$ conducted a double-blind, randomized trial with placebo control to evaluate the effects of corticosteroids (Betamethasone, Dexamethasone, Methylprednisolone) in approximately equivalent doses (8 mg Dexamethasone/day) and to compare their effects with that of Tenoxicam, an anti-inflammatory drug, on both the oedema and ecchymosis in open rhinoplasty with osteotomies. For this study, 40 patients were divided randomly into five groups of 8 patients each, which received, respectively, betamethasone (group 1), Dexamethasone (group 2), Methylprednisolone (group 3), Tenoxicam (group 4), and placebo (group 5). Open rhinoplasty with osteotomies was performed by the same surgeon with the patient under general anaesthesia. Drugs were administered just before the induction of anaesthesia and continued for 3 days. Only acetaminophen was used to control postoperative analgesia. Digital photographs of each patient were taken on postoperative days 1, 3 and 7. Scoring was performed separately for eyelid swelling and ecchymosis by three observers independently using a graded scale from 0 to 4 . No statistically significant differences existed among the 
five groups in terms of age, sex, duration of surgery, amount of bleeding and intravenous fluid administration during the surgery. On postoperative days 1, 3 and 7, no differences in the levels of ecchymosis or oedema among the steroid groups, the Tenoxicam group and the control groups were observed. In conclusion, the authors observed no significant differences among the different kinds of steroids administered in equivalent doses (8 $\mathrm{mg}$ Dexamethasone/day). Steroids used in these doses were not effective in preventing or reducing oedema and ecchymosis after open rhinoplasty with osteotomies. Tenoxicam also was not effective. No complications caused by the use of steroids were observed during the 6-month follow-up.

Gurlek et al (2009). ${ }^{7}$ performed a study on 40 patients under general anaesthesia. Patients were divided randomly into five groups ( 8 patients each group); the groups comprised a single $250 \mathrm{mg}$ dose of Methylprednisolone (Group I), a single $500 \mathrm{mg}$ dose of Methylprednisolone (Group II), four $250 \mathrm{mg}$ doses of Methylprednisolone (Group III) and four $50 \mathrm{mg}$ doses of Methylprednisolone (Group IV) and placebo (Group V). Digital photographs were taken of each patient on the first, third and seventh postoperative days. Scorings of eyelid swelling and ecchymosis were evaluated separately using a graded scale from 0 to 4 by three observers independently. Clinically and statistically significant difference was observed in the decrease of both ecchymosis and oedema, between the placebo and high dose Methylprednisolone groups, which is effective to prevent and to decrease both the ecchymosis and oedema in open rhinoplasty with osteotomies. No complication was observed due to steroid usage. Facial swelling is common after fronto-orbital advancement procedure. Oedema and closure of the palpebral fissures can lead to prolonged hospitalization.

A study to determine if perioperative corticosteroid shortens hospital stay after fronto-orbital advancement was carried out by Clune et al (2010). ${ }^{28}$ Consecutive children younger than 2 years who underwent primary fronto-orbital advancement were categorized into 2 groups: group 1 patients were not given corticosteroid; group 2 patients received tapered perioperative Dexamethasone. Primary outcome variables included length of hospital stay and infection rate. A total of 161 patients were included in the study. Hospitalization was significantly shorter for group 2 (median duration, $3.0 \mathrm{~d}$ ) than group 1 (median duration, $5.0 \mathrm{~d}$ ). Infection rates did not differ between groups. Perioperative corticosteroid reduced hospitalization after fronto-orbital advancement without increasing the incidence of postoperative infection. The cost of postoperative hospital care was reduced by $27.2 \%$.

The use of corticosteroids to control postoperative oedema is controversial. Thus, there is a need for more research to objectively measure the effect of steroids on oedema and if beneficial to determine the optimal drug regimen.

\section{AIMS AND OBJECTIVES}

To evaluate the efficacy of following corticosteroids in reducing facial oedema after craniofaciomaxillary surgery,

1. Dexamethasone $8 \mathrm{mg}$ intravenously at the end of procedure.

2. Triamcinolone $0.7 \mathrm{mg} / \mathrm{kg}$ the local infiltration at the end of procedure.

\section{MATERIALS AND METHODS}

This study was undertaken at Postgraduate Institute of Medical Education and Research (PGIMER), Chandigarh, India from July 2009 to October 2010 in the Department of Plastic and Reconstructive Surgery and Unit of Oral and Maxillofacial Surgery, Oral Health Sciences Centre.

\section{Clinical Study Design}

A prospective double-blind study was performed in patients undergoing craniofaciomaxillary surgery over a period from July 09 - October 10 .

\section{Inclusion Criteria}

Patients undergoing elective craniofaciomaxillary procedures included Cranioplasty, Fronto-orbital advancements, rhinoplasty, orbital procedures and surgeries on the maxilla and mandible.

\section{Exclusion Criteria}

- Patients with ocular herpes, tuberculosis, primary glaucoma, acute psychosis and allergy.

- Peptic ulcer disease or patients on NSAIDs.

- Diabetes mellitus.

- Osteoporosis.

- Patients with any of the known risk factors for avascular necrosis.

- $\quad$ Aspirin sensitive asthmatics.

Faciomaxillary injuries in acute phase were not included because of compounding facial oedema at presentation.

A prospective randomized study was conducted to evaluate the role of corticosteroids in reduction of postoperative facial oedema in craniofaciomaxillary surgeries. Informed consent was taken in all patients. Patients in Group 1 received Dexamethasone $8 \mathrm{mg.26,27}$ intravenously at the end of the procedure. Patients in Group 2 received local infiltration of $0.7 \mathrm{mg} / \mathrm{kg}$ Triamcinolone acetate. ${ }^{25}$ at the end of procedure. Patients in Group 3 received neither Dexamethasone nor Triamcinolone and served as controls. Patients received $50 \mathrm{mg}$ Diclofenac sodium IV/IM and children below 8 yr. received Paracetamol $15 \mathrm{mg} / \mathrm{kg}$ for postoperative analgesia.

A log book was prepared that randomized the 34 patients to Dexamethasone, Triamcinolone and control group. Prior to arrival of the operative surgeon, the resident would determine the group assignment for the patient by sealed envelope technique. The operative surgeon was not informed of the patient's randomization status. The patient's name, age, sex and date of operation, diagnosis were recorded. Any untoward intraoperative or postoperative complications also were recorded in the log.

Facial oedema was evaluated on day 1,2 and 3. Facial oedema was measured with the tragus of the ear as the pivot point using measuring tape (Fig. 1, 2, 3). Measurements were taken on the day of admission and first three postoperative days. Measurements were repeated and averaged on both sides of the face. The sum total of these measurements was taken as Facial size. All patients underwent digital photography.8,29 with standard views (Full face front, Oblique, and Profile; Submental vertical and oblique views and supracranial view). The photographs were taken at admission and 48 hrs. following surgery. Facial oedema was graded in various aesthetic units of face like periorbital, forehead, cheek 
and mandibular regions from the pictures at 48 hrs. postoperatively. Facial oedema on photography was rated by three independent plastic surgery residents who were blinded to the study. A scale of 1 to $4(1=$ minimal, $4=$ massive facial swelling) in Periorbital (Fig. 3) and a scale of 1 to 3 (1=minimal; $3=$ =maximum) in Forehead, Malar and Mandibular regions as compared with the preoperative appearance was used.

Thus, our study had two tools to assess facial swelling. Facial size measurements served as objective assessment while the facial oedema grading based on pre-op and $48 \mathrm{hrs}$. Postop photographs served as semi-objective tool.

\section{Facial Size Measurement. ${ }^{30}$}

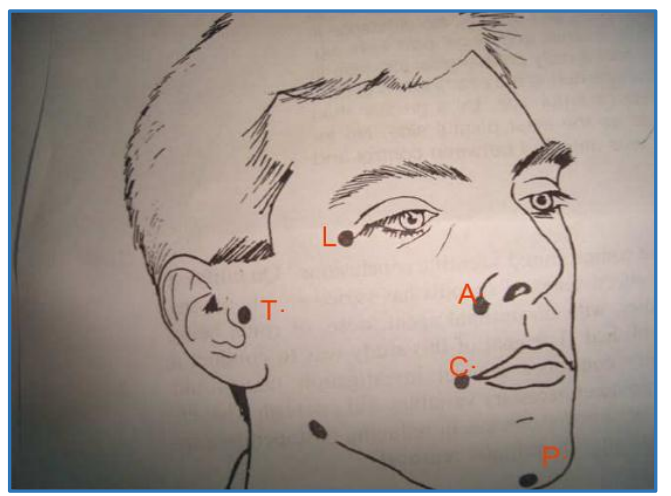

Fig. 1: Diagram showing Facial Landmarks: Tragus (T), Lateral Canthus (L), Alar Base (A), Oral Commissure $(C)$, and Pogonion $(P)$

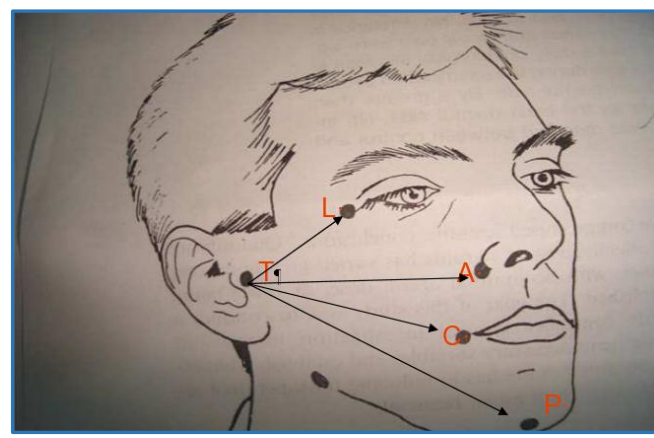

Fig. 2: Diagram of Technique for Measuring Facial Size with the Tragus (T) Of Ear as a Base Point

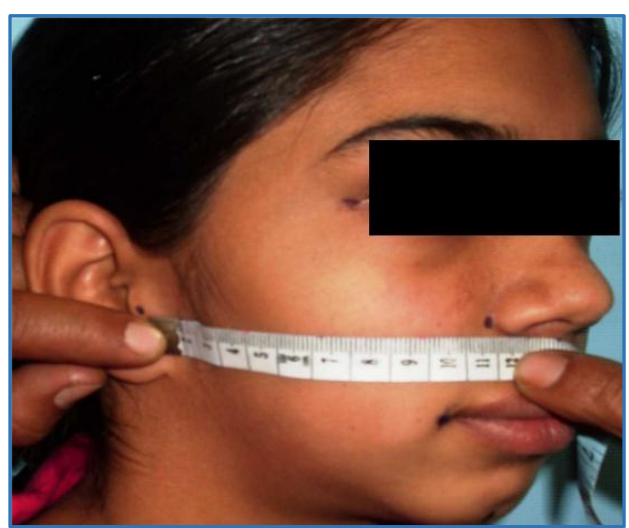

Fig. 3. Photograph showing the Measurement of Facial Size

\section{THE GRADING SCALES WERE DEVISED AS GIVEN BELOW}

A. Forehead

Grade 1: Minimal, forehead wrinkles well preserved.

Grade 2: Moderate, loss of forehead wrinkles.

Grade 3: Severe, gross swelling or boggy swelling.

B. Periorbital. ${ }^{26}$ (Fig. 4)

Grade 1: Minimal.

Grade 2: Covering over iris.

Grade 3: Extending to pupil.

Grade 4: Massive oedema.

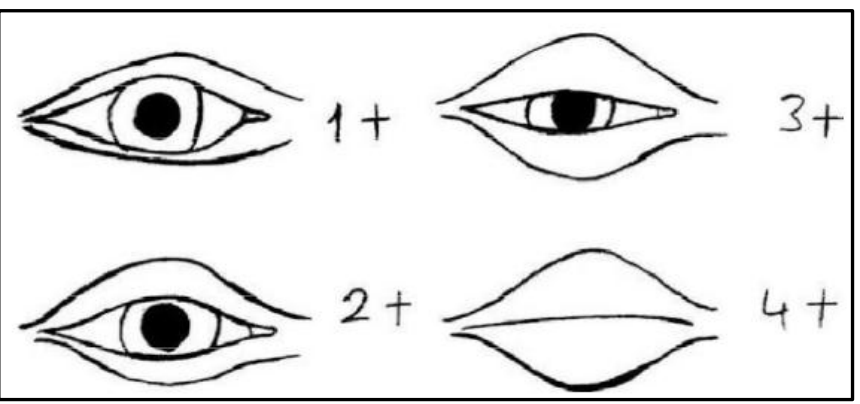

Fig. 4: Grading of Periorbital Oedema +1 (Minimal), +2 (Covering to Iris), +3 (Extending to Pupil), +4 (Massive Oedema)

\section{MALAR ZONE}

Grade 1: Malar eminence easily visible. Grade 2: Malar eminence obscured by oedema. Grade 3: Gross oedema.

\section{MANDIBULAR}

Grade 1: Mandibular outline easily visible.

Grade 2: Mandibular outline not easily visible.

Grade 3: Gross oedema.

\section{RESULTS}

Age

A total of 34 patients were included in the study. Group 1 (Dexamethasone) had 14 patients. Group 2 (Triamcinolone) and Group 3 (Control) had 10 patients each. The study had patients who aged from $1 \mathrm{yr}$. to $50 \mathrm{yr}$. In Group 1, minimum age was $1 \mathrm{yr}$. and maximum was $50 \mathrm{yrs}$. with a mean age of 17.7 yrs. In Group 2, minimum age was 3 yr. and maximum was $28 \mathrm{yr}$. with a mean age of $13.3 \mathrm{yr}$. In Group 3, minimum age was $1 \mathrm{yr}$. and maximum was $32 \mathrm{yrs}$. with a mean age of $16.9 \mathrm{yr}$. By applying ANOVA test for age in 3 groups (Table 1, Fig. 5), $\mathrm{P}$ value was found to be 0.668 . Therefore, age in all 3 groups were matched and not statistically different. 
AGE

\begin{tabular}{|c|c|c|c|c|c|c|c|c|}
\hline \multirow[t]{2}{*}{ Group } & \multirow[t]{2}{*}{$\mathbf{N}$} & \multirow[t]{2}{*}{ Mean Age (Yr.) } & \multirow[t]{2}{*}{ Std. Deviation } & \multirow[t]{2}{*}{ Std. Error } & \multicolumn{2}{|c|}{$\begin{array}{c}\text { 95\% Confidence } \\
\text { Interval for } \\
\text { Mean }\end{array}$} & \multirow[t]{2}{*}{ Min. } & \multirow[t]{2}{*}{ Max. } \\
\hline & & & & & $\begin{array}{l}\text { Lower } \\
\text { Bound }\end{array}$ & $\begin{array}{l}\text { Upper } \\
\text { Bound }\end{array}$ & & \\
\hline $\begin{array}{c}\text { Dexamethasone } \\
\text { Group }\end{array}$ & 14 & 17.7143 & 14.64676 & 3.91451 & 9.2575 & 26.1711 & 1.00 & 50.00 \\
\hline $\begin{array}{c}\text { Triamcinolone } \\
\text { Group }\end{array}$ & 10 & 13.3000 & 9.70739 & 3.06974 & 6.3558 & 20.2442 & 3.00 & 28.00 \\
\hline Control Group & 10 & 16.9000 & 10.28969 & 3.25389 & 9.5392 & 24.2608 & 1.00 & 32.00 \\
\hline Total & 34 & 16.1765 & 11.94805 & 2.04907 & 12.0076 & 20.3453 & 1.00 & 50.00 \\
\hline
\end{tabular}

\begin{tabular}{|c|c|}
\hline \multicolumn{2}{|c|}{ ANOVA Age } \\
\hline F & P-VALUE \\
\hline .409 & .668 \\
\hline
\end{tabular}

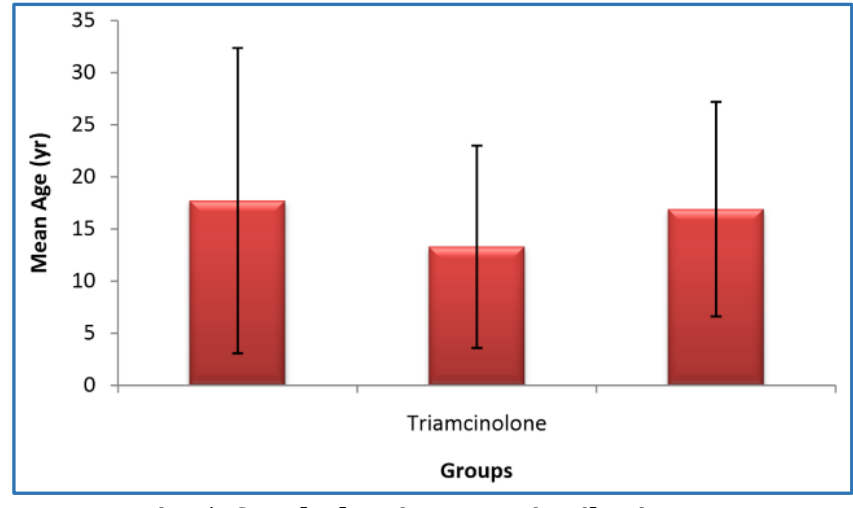

Fig. 5: Graph showing Age Distribution

\section{Sex}

The study had patients of both gender. Dexamethasone group had 8 male and 6 female patients. Triamcinolone group had 4 male and 6 female patients and control group had 6 male and 4 female patients (Table 2, Fig. 6). By applying Chi-square test, $P$ value found to be 0.6157 . Therefore, gender was matched and not statistically different.

\begin{tabular}{|c|c|c|}
\hline Group & Male & Female \\
\hline Dexamethasone & 8 & 6 \\
\hline Triamcinolone & 4 & 6 \\
\hline Control & 6 & 4 \\
\hline \multicolumn{2}{|c|}{ Table 2: Sex Distribution } \\
\hline
\end{tabular}

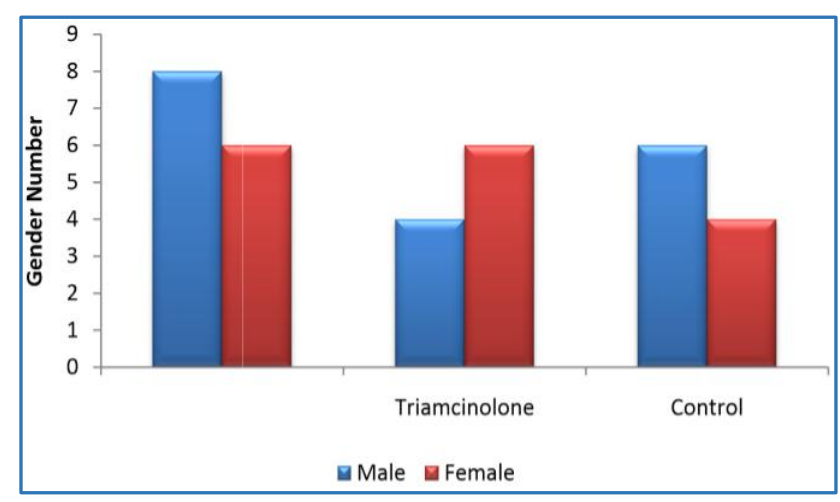

Fig. 6: Graph showing Sex Distribution

\section{Duration of Surgery}

The study had various craniofaciomaxillary procedures with durations from $1.0 \mathrm{hr}$. to $7.5 \mathrm{hrs}$. Group 1 (Dexamethasone) had duration of surgeries with minimum of $1 \mathrm{hr}$. and maximum of 5.5 hrs. Group 2 (Triamcinolone) had duration of surgery with minimum of $1.0 \mathrm{hr}$. and maximum of $7.5 \mathrm{hrs}$. Group 3 (Control) had duration of surgeries with minimum of $1.0 \mathrm{hr}$. and maximum of 4.0 hrs. (Table 3, Fig. 7). By applying ANOVA test for duration of surgery in 3 groups, $P$ value found to be 0.434 . Therefore, age in all 3 groups, duration of surgery was matched and not statistically significant different.

\begin{tabular}{|c|c|c|c|c|c|c|c|c|}
\hline \multirow[t]{2}{*}{ Group } & \multirow[t]{2}{*}{$\mathbf{N}$} & \multirow[t]{2}{*}{ Mean } & \multirow[t]{2}{*}{$\begin{array}{c}\text { Std. } \\
\text { Deviation }\end{array}$} & \multirow[t]{2}{*}{$\begin{array}{c}\text { Std. } \\
\text { Error }\end{array}$} & \multicolumn{2}{|c|}{$\begin{array}{c}95 \% \\
\text { Confidence } \\
\text { Interval for } \\
\text { Mean } \\
\end{array}$} & \multirow[t]{2}{*}{ Min. } & \multirow[t]{2}{*}{ Max. } \\
\hline & & & & & $\begin{array}{l}\text { Lower } \\
\text { Bound }\end{array}$ & $\begin{array}{l}\text { Upper } \\
\text { Bound }\end{array}$ & & \\
\hline $\begin{array}{c}\text { Dexamethasone } \\
\text { Group }\end{array}$ & 14 & 3.536 & 1.2628 & .3375 & 2.807 & 4.265 & 1.0 & 5.5 \\
\hline $\begin{array}{c}\text { Triamcinolone } \\
\text { Group }\end{array}$ & 10 & 3.950 & 2.1009 & .6644 & 2.447 & 5.453 & 1.0 & 7.5 \\
\hline Control Group & 10 & 3.056 & .8457 & .2819 & 2.405 & 3.706 & 1.0 & 4.0 \\
\hline \multicolumn{9}{|c|}{ Table 3: Duration of Surgery } \\
\hline
\end{tabular}

\begin{tabular}{|c|c|}
\hline \multicolumn{2}{|c|}{$\begin{array}{c}\text { ANOVA } \\
\text { Duration of Surgery (Hr) }\end{array}$} \\
\hline $\mathrm{F}$ & P-VALUE \\
\hline .859 & .434 \\
\hline
\end{tabular}

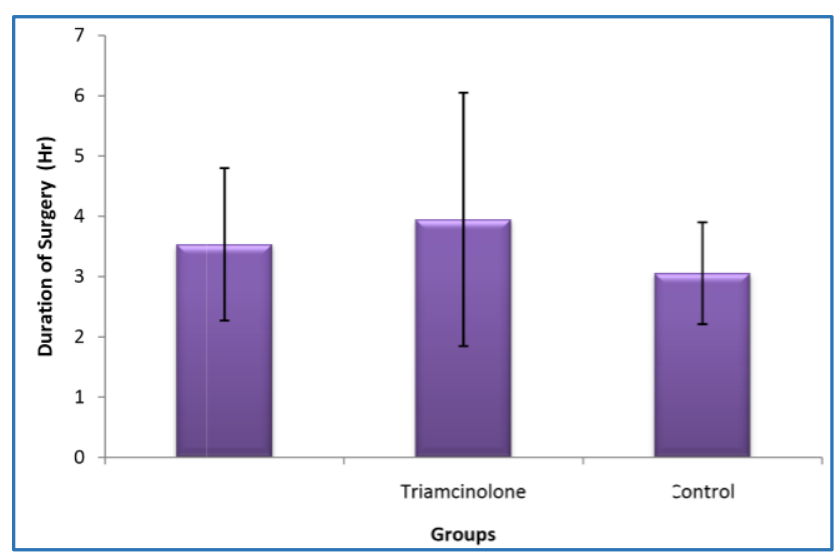

Fig. 7: Graph showing The Duration of Surgery in the Groups 


\section{Facial Size}

Facial size was the objective measurement of the face from Tragus to Lateral Canthus, Alar base, Oral commissure and Pogonion. Measurements were repeated and averaged on both sides. These measurements were taken on day of admission, post-operative day 1, 2 and 3 (Table 4, Fig. 8, and Fig. 9). It was observed that there was change in the facial size between day of admission, post-operative day 1, 2 and 3 within each group. We observed that there was postoperative facial oedema on POD1, and increased on POD2 and then started declining within each group. By applying ANOVA, the Facial size between the 3 groups on admission, POD1, POD2, POD3 were found to be non-significant.

\begin{tabular}{|c|c|c|c|c|c|c|c|c|c|}
\hline & & \multirow[t]{2}{*}{$\mathbf{N}$} & \multirow[t]{2}{*}{ Mean cm } & \multirow[t]{2}{*}{ Std. Deviation } & \multirow[t]{2}{*}{ Std. Error } & \multicolumn{2}{|c|}{$\begin{array}{l}\text { 95\% Confidence } \\
\text { Interval for } \\
\text { Mean }\end{array}$} & \multirow[t]{2}{*}{ Min. } & \multirow[t]{2}{*}{ Max. } \\
\hline & & & & & & $\begin{array}{l}\text { Lower } \\
\text { Bound }\end{array}$ & $\begin{array}{l}\text { Upper } \\
\text { Bound }\end{array}$ & & \\
\hline \multirow{3}{*}{$\begin{array}{c}\text { FS ON } \\
\text { Admission }\end{array}$} & $\begin{array}{c}\text { Dexamethasone } \\
\text { Group }\end{array}$ & 14 & 79.293 & 9.8435 & 2.6308 & 73.609 & 84.976 & 57.0 & 91.0 \\
\hline & $\begin{array}{c}\text { Triamcinolone } \\
\text { Group }\end{array}$ & 10 & 79.190 & 9.4366 & 2.9841 & 72.439 & 85.941 & 65.0 & 92.0 \\
\hline & Control group & 10 & 83.400 & 9.0333 & 2.8566 & 76.938 & 89.862 & 73.0 & 98.0 \\
\hline \multirow{3}{*}{ FS ON POD1 } & $\begin{array}{c}\text { Dexamethasone } \\
\text { Group }\end{array}$ & 14 & 82.621 & 9.8808 & 2.6407 & 76.916 & 88.326 & 59.2 & 96.0 \\
\hline & $\begin{array}{c}\text { Triamcinolone } \\
\text { Group }\end{array}$ & 10 & 81.890 & 8.6345 & 2.7305 & 75.713 & 88.067 & 68.0 & 92.0 \\
\hline & Control group & 10 & 86.250 & 9.5692 & 3.0260 & 79.405 & 93.095 & 73.0 & 101.5 \\
\hline \multirow{3}{*}{ FS ON POD2 } & $\begin{array}{c}\text { Dexamethasone } \\
\text { Group }\end{array}$ & 14 & 84.500 & 10.4366 & 2.7893 & 78.474 & 90.526 & 60.5 & 98.0 \\
\hline & $\begin{array}{c}\text { Triamcinolone } \\
\text { Group }\end{array}$ & 10 & 84.360 & 7.0064 & 2.2156 & 79.348 & 89.372 & 72.0 & 93.0 \\
\hline & Control group & 10 & 88.600 & 8.2724 & 2.6160 & 82.682 & 94.518 & 79.0 & 102.0 \\
\hline \multirow{3}{*}{ FS ON POD3 } & $\begin{array}{c}\text { Dexamethasone } \\
\text { Group }\end{array}$ & 14 & 81.500 & 10.0352 & 2.6820 & 75.706 & 87.294 & 57.2 & 93.0 \\
\hline & $\begin{array}{c}\text { Triamcinolone } \\
\text { Group }\end{array}$ & 10 & 82.540 & 7.2707 & 2.2992 & 77.339 & 87.741 & 71.0 & 92.0 \\
\hline & Control Group & 10 & 85.650 & 8.5669 & 2.7091 & 79.522 & 91.778 & 76.0 & 99.5 \\
\hline \multicolumn{10}{|c|}{ Table 4: Facial Size } \\
\hline
\end{tabular}

\begin{tabular}{|c|c|c|}
\hline \multicolumn{2}{|c|}{ ANOVA } & \multirow[b]{2}{*}{ P-Value } \\
\hline & $\mathbf{F}$ & \\
\hline FS On Admission & .674 & .517 \\
\hline FS On POD1 & .630 & .539 \\
\hline FS On POD2 & .766 & .474 \\
\hline FS On POD3 & .658 & .525 \\
\hline
\end{tabular}
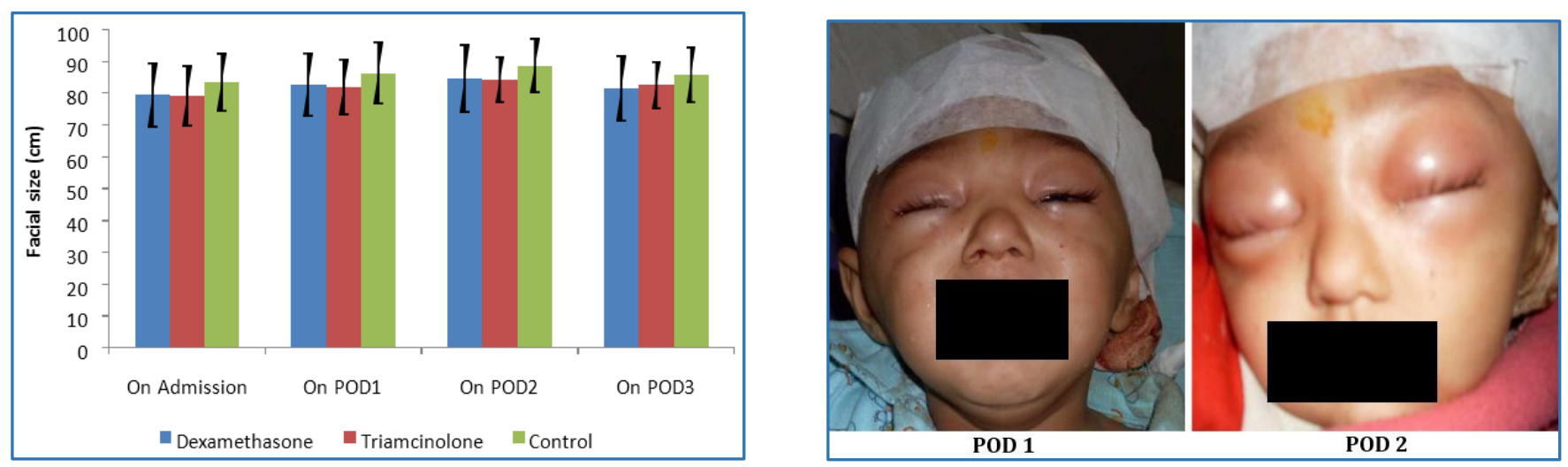

Fig. 8: Graph showing Facial Size Distribution 


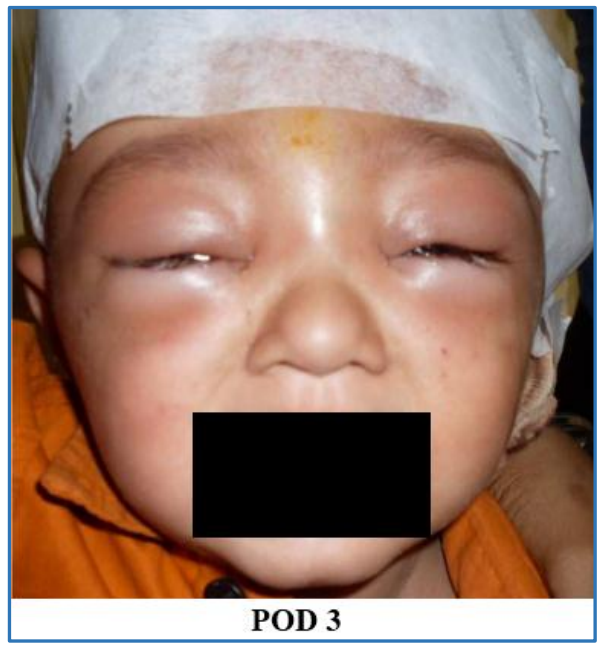

Fig. 9: Facial Oedema Trend on Post-operative Day 1, 2 and 3

\section{DIFFERENCE IN THE FACIAL SIZE WITHIN THE GROUPS}

We studied the change in the facial size postoperatively with the facial size on day of admission as the baseline. DIFFSD1 is the difference in facial size on POD1 from facial size on admission. DIFFSD2 is the difference in facial size on POD2 from facial size on admission. DIFFSD3 is the difference in facial size on POD3 from facial size on admission. When put to ANOVA test, there was no significant change in the facial size differences on POD1 (DIFFSD1), POD2 (DIFFSD2), and POD3.

(DIFFSD3) within the Dexamethasone, Triamcinolone and Control Groups. (Table 5, Fig. 10).

\section{Descriptives}

\begin{tabular}{|c|c|c|c|c|c|c|c|c|c|}
\hline & & \multirow[t]{2}{*}{$\mathbf{N}$} & \multirow[t]{2}{*}{ Mean $(\mathrm{cm})$} & \multirow[t]{2}{*}{$\begin{array}{c}\text { Std. } \\
\text { Deviation }\end{array}$} & \multirow[t]{2}{*}{ Std. Error } & \multicolumn{2}{|c|}{$\begin{array}{c}95 \% \\
\text { Confidence } \\
\text { Interval } \\
\text { for Mean }\end{array}$} & \multirow[t]{2}{*}{ Min. } & \multirow[t]{2}{*}{ Max. } \\
\hline & & & & & & $\begin{array}{l}\text { Lower } \\
\text { Bound }\end{array}$ & $\begin{array}{l}\text { Upper } \\
\text { Bound }\end{array}$ & & \\
\hline \multirow{3}{*}{ DIFFFSD1 } & $\begin{array}{c}\text { Dexamethasone } \\
\text { Group }\end{array}$ & 14 & 3.3286 & 1.13370 & .30299 & 2.6740 & 3.9832 & 2.00 & 5.50 \\
\hline & $\begin{array}{l}\text { Triamcinolone } \\
\text { Group }\end{array}$ & 10 & 2.7000 & 2.42899 & .76811 & .9624 & 4.4376 & .00 & 6.50 \\
\hline & Control Group & 10 & 2.8500 & 1.27039 & .40173 & 1.9412 & 3.7588 & .00 & 4.50 \\
\hline \multirow{3}{*}{ DIFFFSD2 } & $\begin{array}{l}\text { Dexamethasone } \\
\text { Group }\end{array}$ & 14 & 5.2071 & 2.15958 & .57717 & 3.9602 & 6.4540 & 2.00 & 9.50 \\
\hline & $\begin{array}{c}\text { Triamcinolone } \\
\text { Group }\end{array}$ & 10 & 5.1700 & 4.42092 & 1.39802 & 2.0075 & 8.3325 & .00 & 12.00 \\
\hline & Control Group & 10 & 5.2000 & 1.67000 & .52810 & 4.0054 & 6.3946 & 2.00 & 8.00 \\
\hline \multirow{3}{*}{ DIFFFSD3 } & $\begin{array}{c}\text { Dexamethasone } \\
\text { Group }\end{array}$ & 14 & 2.2071 & 1.80447 & .48226 & 1.1653 & 3.2490 & .00 & 5.00 \\
\hline & $\begin{array}{c}\text { Triamcinolone } \\
\text { Group }\end{array}$ & 10 & 3.3500 & 3.83703 & 1.21337 & .6052 & 6.0948 & .00 & 10.50 \\
\hline & Control Group & 10 & 2.2500 & 1.33853 & .42328 & 1.2925 & 3.2075 & .00 & 4.00 \\
\hline
\end{tabular}

\begin{tabular}{|c|c|c|}
\hline \multicolumn{3}{|c|}{ ANOVA } \\
\hline & F & P-VALUE \\
\hline DIFFFSD1 & .485 & .621 \\
\hline DIFFFSD2 & .001 & .999 \\
\hline DIFFFSD3 & .726 & .492 \\
\hline
\end{tabular}

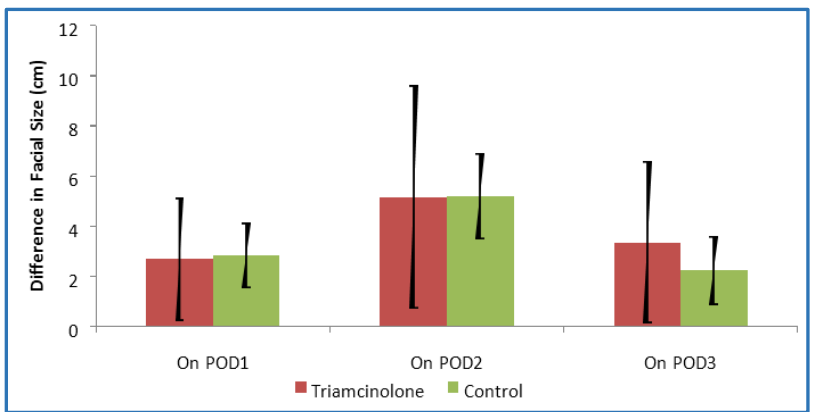

Fig. 10: Graph showing Difference in Facial Sizes on POD1, POD2, POD3 within Groups

\section{Facial Oedema Score}

Facial oedema was also assessed semi-objectively by grading the oedema in various facial regions using the grading scales. Gradings were given by comparing the photographs at admission and $48 \mathrm{hrs}$. postoperatively. Mean facial oedema scores in Dexamethasone, Triamcinolone and Control Group were 21.85, 20.10, 24.30 respectively (Table 6, Fig. 11). By applying Non-parametric Kruskal-Wallis test, $\mathrm{P}$ value was found to be 0.403 . Hence, facial oedema scores were not statistically significant. 


\begin{tabular}{|c|c|c|c|c|c|c|}
\hline & \multicolumn{5}{|c|}{ Facial Oedema Score } & \\
\hline Group & Mean & $\mathbf{N}$ & $\begin{array}{c}\text { Std. } \\
\text { Deviation }\end{array}$ & Min. & Max. & Median \\
\hline $\begin{array}{c}\text { Dexamethasone } \\
\text { Group }\end{array}$ & 21.857 & 14 & 6.3834 & 12.0 & 30.0 & 21.000 \\
\hline $\begin{array}{c}\text { Triamcinolone } \\
\text { Group }\end{array}$ & 20.100 & 10 & 6.7897 & 12.0 & 30.0 & 22.500 \\
\hline Control Group & 24.300 & 10 & 7.6746 & 12.0 & 33.0 & 27.000 \\
\hline Total & $\mathbf{2 2 . 0 5 9}$ & $\mathbf{3 4}$ & $\mathbf{6 . 8 8 4 1}$ & $\mathbf{1 2 . 0}$ & $\mathbf{3 3 . 0}$ & $\mathbf{2 2 . 5 0 0}$ \\
\hline \multicolumn{7}{|c|}{ Table 6: Facial Oedema Scores within the Groups } \\
\hline
\end{tabular}

\begin{tabular}{|c|c|c|}
\hline Group & N & Mean Rank \\
\hline Dexamethasone Group & 14 & 17.18 \\
\hline Triamcinolone Group & 10 & 14.80 \\
\hline Control Group & 10 & 20.65 \\
\hline Total & 34 & \\
\hline \multicolumn{2}{|c|}{ Non-Parametric Tests, Kruskal-Ranks } \\
\hline
\end{tabular}

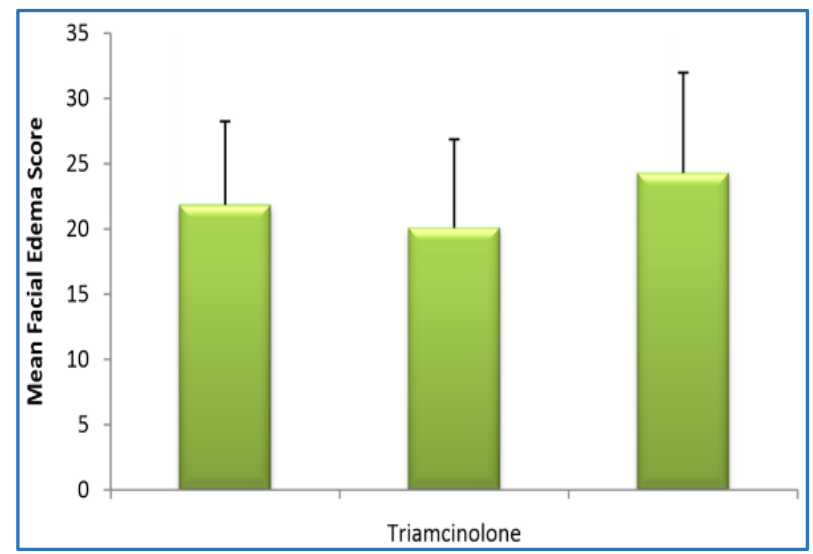

Fig. 11: Graph showing Facial Oedema Score within Groups

Correlation between Facial Oedema Score and Difference in Facial Size on POD2 (DIFFSD2)

The facial oedema score was determined by grading of facial oedema by three independent observers from digital photographs taken on POD2. DIFFSD2 was the difference in measurements in the facial size between the day of admission and postoperative day 2. By applying the nonparametric correlations (Table 6), it was found that the facial oedema score and DIFFSD2 correlated and P value was found to be 0.006. Thus, facial oedema score and DIFFSD2, the semiobjective and objective methods of facial oedema assessment correlated. The above nonparametric correlation (Table 6) also showed that the duration of surgery and facial oedema did not correlate $(\mathrm{P}=0.015)$. Also, duration of surgery and difference in measurements in the facial size between the day of admission and postoperative day 2 did not correlate. $(\mathrm{P}=0.067)$.

Nonparametric Correlations

\begin{tabular}{|c|c|c|c|c|c|}
\hline & & & $\begin{array}{c}\text { Duration } \\
\text { of Surgery (Hr) }\end{array}$ & $\begin{array}{c}\text { Facial } \\
\text { Oedema } \\
\text { Score }\end{array}$ & DIFFFSD2 \\
\hline \multirow{9}{*}{ Spearman's } & \multirow{3}{*}{$\begin{array}{c}\text { Duration } \\
\text { of } \\
\text { Surgery }(\mathrm{Hr})\end{array}$} & $\begin{array}{l}\text { Correlation } \\
\text { Coefficient }\end{array}$ & 1.000 & $.421\left(^{*}\right)$ & .322 \\
\hline & & P-Value & . & .015 & .067 \\
\hline & & $\mathrm{N}$ & 33 & 33 & 33 \\
\hline & \multirow{3}{*}{$\begin{array}{c}\text { Facial } \\
\text { Oedema } \\
\text { Score }\end{array}$} & $\begin{array}{c}\text { Correlation } \\
\text { Coefficient }\end{array}$ & $.421\left(^{*}\right)$ & 1.000 & $.464\left(^{* *}\right)$ \\
\hline & & P-VALUE & .015 & . & .006 \\
\hline & & $\mathrm{N}$ & 33 & 34 & 34 \\
\hline & \multirow{3}{*}{ DIFFFSD2 } & Correlation Coefficient & .322 & $.464(* *)$ & 1.000 \\
\hline & & P-Value & .067 & .006 & . \\
\hline & & $\mathrm{N}$ & 33 & 34 & 34 \\
\hline \multicolumn{4}{|c|}{$\begin{array}{c}{ }^{*} \text { Correlation is significant at the } \\
0.05 \text { level ( } 2 \text {-tailed). }\end{array}$} & & \\
\hline \multicolumn{4}{|c|}{$\begin{array}{c}\text { ** Correlation is significant at the } \\
0.01 \text { level ( } 2 \text {-tailed). }\end{array}$} & & \\
\hline
\end{tabular}

\section{Facial Oedema Region Wise}

We compared the facial oedema on different regions of face namely Forehead, Periorbital, Malar and Mandibular regions (Table 7, Fig. 12). We found that oedema was maximum in the periorbital region in all the three groups, followed by oedema on forehead, malar and mandibular regions. 


\begin{tabular}{|c|c|c|c|c|c|c|c|c|}
\hline \multirow{2}{*}{ Region } & \multirow{2}{*}{$\mathbf{N}$} & \multirow{2}{*}{ Mean Score } & \multirow{2}{*}{ Std. Deviation } & \multirow{2}{*}{ Std. Error } & \multicolumn{2}{|c|}{$\begin{array}{l}95 \% \text { Confidence } \\
\text { Interval for Mean }\end{array}$} & \multirow{2}{*}{ Min. } & \multirow{2}{*}{ Max. } \\
\hline & & & & & Lower Bound & $\begin{array}{l}\text { Upper } \\
\text { Bound }\end{array}$ & & \\
\hline Forehead & 34 & 2.030 & .9180 & .1598 & 1.705 & 2.356 & 1.0 & 3.0 \\
\hline Periorbital & 34 & 2.697 & 1.1855 & .2064 & 2.277 & 3.117 & 1.0 & 4.0 \\
\hline Malar & 34 & 1.485 & .6185 & .1077 & 1.266 & 1.704 & 1.0 & 3.0 \\
\hline Mandibular & 34 & 1.091 & .2919 & .0508 & .987 & 1.194 & 1.0 & 3.0 \\
\hline
\end{tabular}

\begin{tabular}{|c|c|}
\hline \multicolumn{2}{|c|}{ ANOVA FE } \\
\hline F & P-Value \\
\hline 23.606 & $<.001^{* *}$ \\
\hline
\end{tabular}

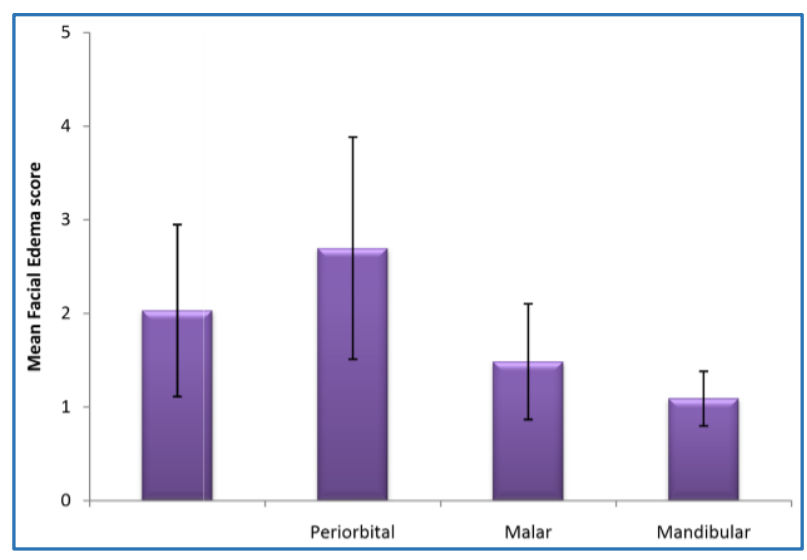

Fig. 12: Comparison of Facial Oedema in Various Facial Regions
Facial Oedema Scores Region Wise within the Groups

Periorbital region oedema was scored from 1 to 4 , while the forehead, malar and mandibular regions were scored from 1 to 3. We also observed that there was direct correlation between forehead and periorbital oedema. (Table 8, Table 9, and Fig. 13).

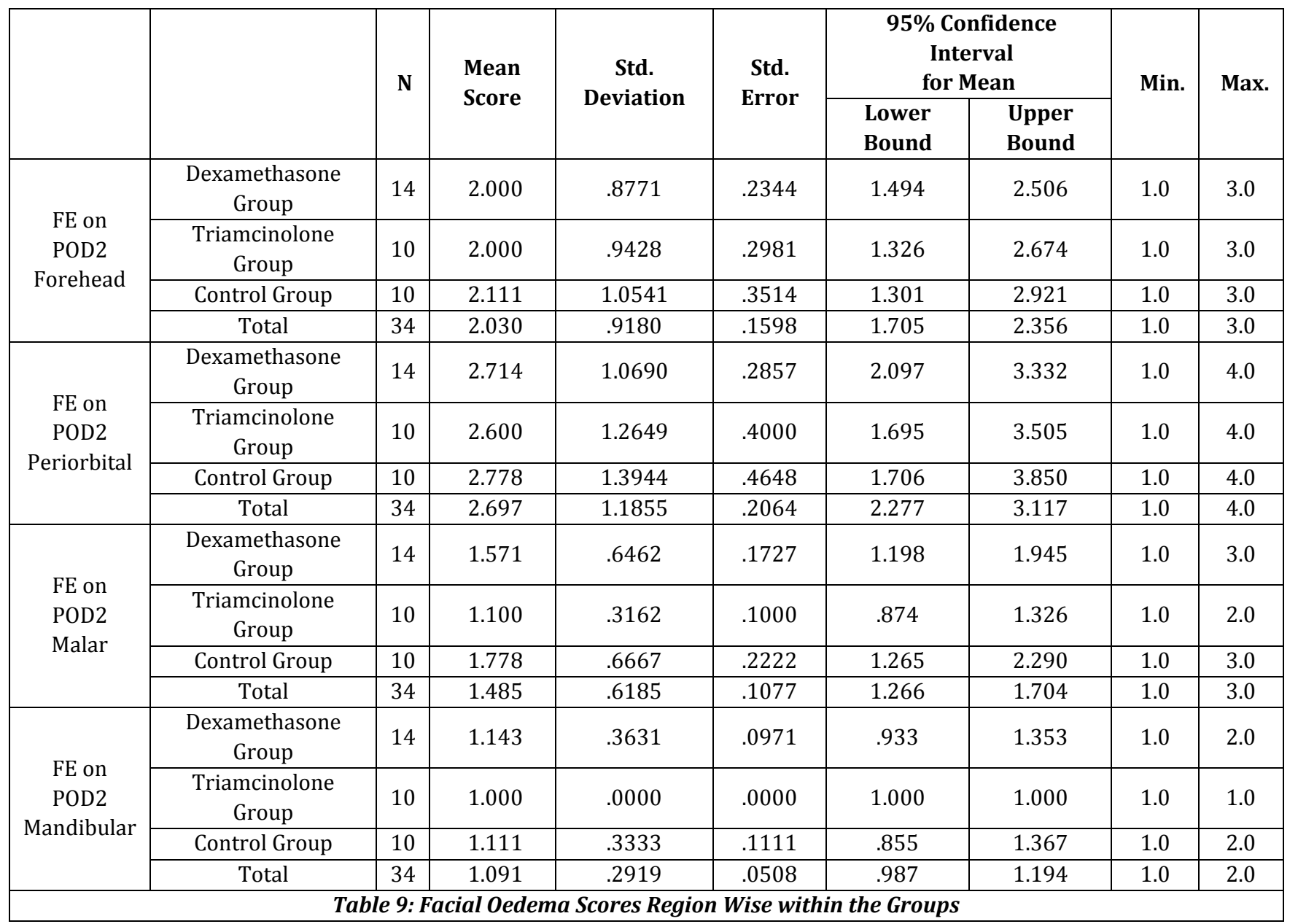




\begin{tabular}{|c|c|c|}
\hline \multicolumn{1}{|c|}{ ANOVA } & \multicolumn{2}{c|}{ P-Value } \\
\hline & F & .956 \\
\hline FE on POD2 Forehead & .045 & .949 \\
\hline FE on POD2 Periorbital & .053 & $.040^{*}$ \\
\hline FE on POD2 Malar & 3.579 & .497 \\
\hline
\end{tabular}

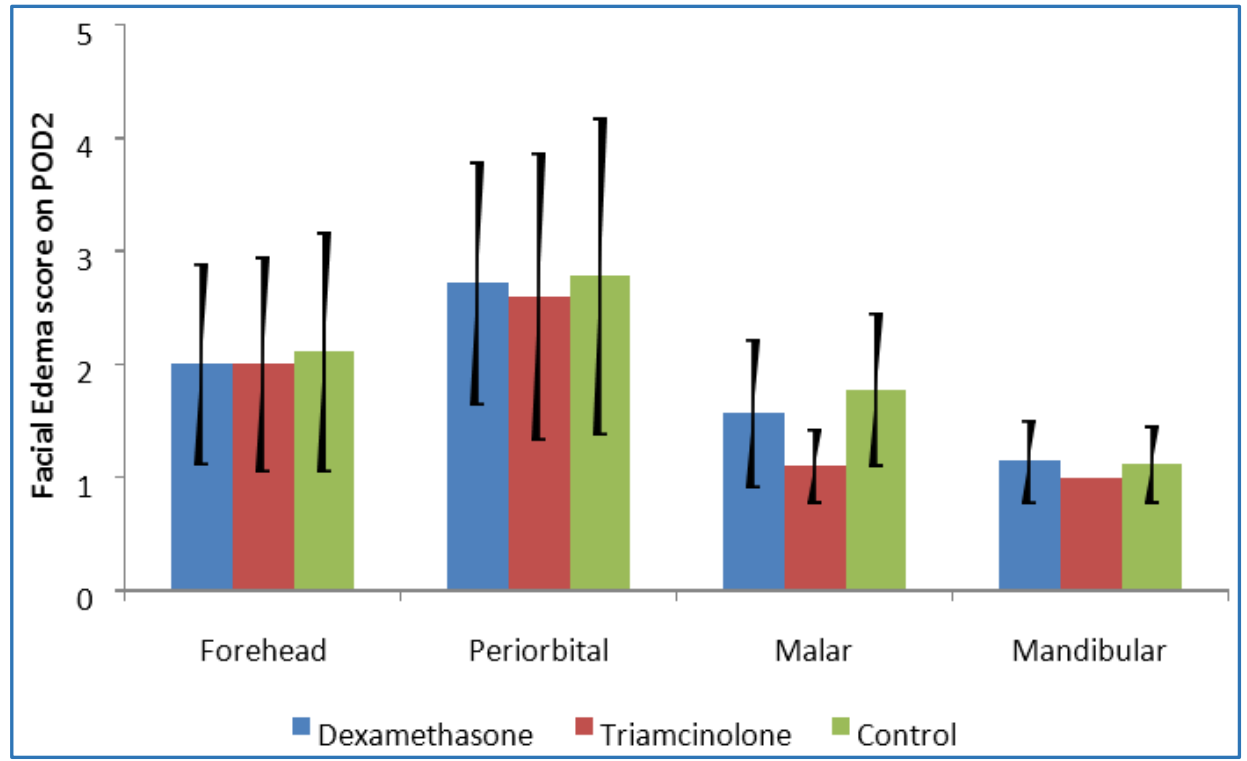

Fig. 13: Graph showing Facial Oedema Region Wise within Groups

\begin{tabular}{|c|c|c|c|c|c|}
\hline Correlations & & $\begin{array}{c}\text { FE on POD2 } \\
\text { Forehead }\end{array}$ & $\begin{array}{r}\text { FE on POD2 } \\
\text { Periorbital } \\
\end{array}$ & $\begin{array}{c}\text { FE on POD2 } \\
\text { Malar }\end{array}$ & $\begin{array}{l}\text { FE on POD2 } \\
\text { Mandibular }\end{array}$ \\
\hline \multirow{3}{*}{$\begin{array}{c}\text { FE on POD2 } \\
\text { Forehead }\end{array}$} & Pearson Correlation & 1 & $.813(* *)$ & .138 & $-.360\left(^{*}\right)$ \\
\hline & P-Value & & .000 & .442 & .039 \\
\hline & $\mathrm{N}$ & 34 & 34 & 34 & 34 \\
\hline \multirow{3}{*}{$\begin{array}{c}\text { FE on POD2 } \\
\text { Periorbital }\end{array}$} & Pearson Correlation & $.813\left(^{* *}\right)$ & 1 & .207 & $-.369\left(^{*}\right)$ \\
\hline & P-Value & .000 & & .249 & .034 \\
\hline & $\mathrm{N}$ & 34 & 34 & 34 & 34 \\
\hline \multirow{3}{*}{$\begin{array}{c}\text { FE on POD2 } \\
\text { Malar }\end{array}$} & Pearson Correlation & .138 & .207 & 1 & $.614(* *)$ \\
\hline & P-Value & .442 & .249 & & .000 \\
\hline & $\mathrm{N}$ & 34 & 34 & 34 & 34 \\
\hline \multirow{2}{*}{$\begin{array}{l}\text { FE on POD2 } \\
\text { Mandibular }\end{array}$} & Pearson Correlation & $-.360\left(^{*}\right)$ & $-.369\left(^{*}\right)$ & $.614\left(^{* *}\right)$ & 1 \\
\hline & P-Value & .039 & .034 & .000 & \\
\hline
\end{tabular}

\section{DISCUSSION}

The oedema after maxillofacial procedures results in significant postoperative morbidity. ${ }^{31}$ It can lead to increased pain, cosmetic deformity, prolonged period of intubation, delay in resumption of normal diet, and can adversely affect the rate of wound healing. These issues delay the patient's discharge from the hospital and a return to his or her normal activities.

Oedema component of the postoperative swelling is an inflammatory reaction to the surgical procedure. Therefore, this may be modified by the use of a strong anti-inflammatory agent such as corticosteroids. ${ }^{17}$

Patients undergoing craniomaxillofacial procedures were randomized into 3 groups. Group 1 received Dexamethasone 8 $\mathrm{mg}$ IV at end of procedure. Group 2 received local infiltration of $0.7 \mathrm{mg} / \mathrm{kg}$ Triamcinolone acetate at the end of procedure. Group 3 received neither IV Dexamethasone nor local Triamcinolone and served as controls. Patients received $50 \mathrm{mg}$
Diclofenac sodium IV/IM and children below 8 yrs. received Paracetamol $15 \mathrm{mg} / \mathrm{kg}$ for postoperative analgesia.

We observed was postoperative facial oedema on POD1, and this peaked on POD2 and then started declining within each group. There was no correlation between the duration of surgery and the postoperative facial oedema on postoperative day 1,2 , 3. In fact, the magnitude of postoperative oedema depends on several factors such as the type of surgery, extent of tissue dissection, bony manipulation and tissue handling. However, quantification of these parameters was not part of this study.

We found that oedema was maximum in the periorbital region in all the three groups followed by oedema on forehead, malar and mandibular regions. This may be due to lax skin and plenty of loose areolar tissue in the periorbital region. Moreover, majority of operative procedures involved this region. 
In all our patients, the presence of oedema in the forehead was associated with periorbital oedema. This may be happening because of trickling of oedema fluid from subaponeurotic space of scalp into the eyelids and periorbital region.

Neil-Dwyer et al25 (2001) conducted a study with preoperative tumescent infiltration using $7 \mathrm{~mL} / \mathrm{kg}$ of a solution consisting of $0.1 \mathrm{mg} / \mathrm{mL}$ Triamcinolone acetate, 0.0125\% Bupivacaine, $0.025 \%$ Lignocaine, 3 units $/ \mathrm{mL}$ Hyaluronidase and 1:1000,000 adrenaline in Hartmann's solution. Eye closure (i.e. inability to open the eyes) was used as a marker for severe facial swelling. The infiltration solution has the advantage of a lower corticosteroid dose than previously reported Dexamethasone based perioperative regimens, thereby minimizing any unwanted metabolic effects. The technique is advocated for the reduction of postoperative facial swelling in craniomaxillofacial surgical patients.

Our study also included a Triamcinolone group, in which the patients were locally administered Inj. Triamcinolone 0.7 $\mathrm{mg} / \mathrm{kg}$, at the end of procedure. We did not use Adrenaline in our infiltration solution. On comparing the results of postoperative facial oedema of Triamcinolone group with control, we did not find significant difference in facial size measurement or facial oedema scores.

A double-blind, randomized study by Eksal Kargi ${ }^{26}$ was designed to determine the efficacy of Dexamethasone in decreasing periorbital oedema and ecchymosis after rhinoplasty using various doses of Dexamethasone. Sixty rhinoplasty patients undergoing hump resection and lateral osteotomy were included in the study and were divided into 6 groups: group 1, single dose of $8 \mathrm{mg}$ IV Dexamethasone 1 hour before the operation; group 2, single dose of $8 \mathrm{mg}$ IV Dexamethasone at the beginning of the operation; group 3, 3 doses of $8 \mathrm{mg}$ IV Dexamethasone 1 hour before the operation, and 24 and 48 hours after the operation; group 4, 3 doses of 8 mg IV Dexamethasone at the beginning of the operation, and 24 and 48 hour after the operation; group 5, 3 doses of $8 \mathrm{mg}$ IV Dexamethasone immediately after the operation, and 24 and 48 hours after the operation; group 6, control, no Dexamethasone administration before or after the operation. Patients were evaluated at 24 hours and days 2, 5, 7 and 10. In the groups using steroid before osteotomy, oedema and ecchymosis were significantly lower during the first 2 days compared with the control group. No significant difference was seen between groups 1 and 2 . When patients were evaluated on day 5 , oedema and ecchymosis were significantly lower in groups 3 and 4 compared with other groups, but there was no difference between them. Group 5 had a significantly higher level of oedema and ecchymosis compared with groups 1 through 4 at 24 hours and at days 2, 5 and 7. There was no significant difference between groups on day 10. In conclusion, if the first dose is given before osteotomy, triple dose steroid application is the best bet for decreasing postoperative oedema and ecchymosis.

In our study, Dexamethasone group patients ( $n=14)$, received a single dose of Dexamethasone $8 \mathrm{mg}$ IV at the end of procedure. We observed no significant difference in the facial size and facial oedema score in the Dexamethasone group compared to control group. This difference in the results could be explained by the fact that authors used Dexamethasone either before or at the beginning of the procedure compared to our study, wherein we injected Dexamethasone at the end of the procedure.

Rapport et $\mathrm{al}^{5}$ (1995) performed a randomized, double blind study. Fifty consecutive facial plasty patients of one surgeon were randomized to steroid and no steroid groups. Steroid group patients received betamethasone $6 \mathrm{mg}$ IM preoperatively. Postoperative scoring of swelling was performed at approximately days 5 and 9 by a single observer. There were no significant differences between the two groups at either postoperative interval or in the rate of improvement. Subgroups of patients who underwent additional procedures also showed no significant differences. They were not able to demonstrate any statistically significant difference in swelling after facial plasty with this steroid regimen. In our study, we used Dexamethasone and when compared with the control group, there was no significant difference in the postoperative oedema.

Owsley et $\mathrm{al}^{6}$ (1996) conducted a prospective, double blinded study of 30 consecutive face lift patients to determine if the administration of corticosteroid medication would reduce postoperative facial oedema. Half the patients received steroid medications in a random fashion. Three independent plastic surgeons who were blinded to the study rated facial swelling by comparing preoperative and postoperative photographs using a scale of 1 to 4 . The data were tabulated and subjected to statistical analysis. There were no significant differences in facial swelling between the steroid treated group and the untreated patients on any occasion. Our study also included photographic evaluation in addition to facial size measurements. We too did not find any significant difference in the reduction of postoperative facial oedema between Dexamethasone group and control group.

Based on a literature review. ${ }^{1}$ an analysis of the steroid regimens and complications reported revealed that steroid use was generally safe. Consideration should be given to withholding steroids in patients with any of the known risk factors for avascular necrosis, in patients who are or recently have been on NSAIDS, and in aspirin-sensitive asthmatics. These patients may be at increased risk for serious adverse effects with the use of steroids. Because of the wide range of physiologic effects elicited by steroids, the clinician should always be alert to the potential risks and contraindications whenever these drugs are to be administered, especially on a long-term basis. Immune and inflammatory responses and the functions of the central nervous system are also suppressed by steroids.

Greatest danger of the administration of exogenous steroids is the potential suppression of the hypothalamic pituitary adrenal axis, which results in adrenal atrophy. ${ }^{32}$ Partial suppression of the hypothalamic-pituitary adrenal axis in short-term, high dose administration of steroids can occur for up to a week, even with a single $8 \mathrm{mg}$ dose of Dexamethasone.1,33 However, this seems to be clinically insignificant, presumably because of the minor stress of craniomaxillofacial surgery and the prolonged biological halflife of the synthetic steroids. A patient may be at increased risk for a hypoadrenal crisis if the axis is suppressed for a longer period of time. Axis suppression could occur unpredictably for weeks to months if steroids are administered at a daily dose greater than about $50 \mathrm{mg}$ of prednisone $(250 \mathrm{mg}$ hydrocortisone equivalent) for more than 5 days. Only two surgeons in the survey ${ }^{1}$ reported using steroids for longer than 
5 days. Both reported a 7-day oral Methylprednisolone regimen whose maximal daily dose of only about $25 \mathrm{mg}$ prednisone equivalent with a taper likely averts a prolonged hypoadrenal state thereafter.

Hoffmann et al (1991). ${ }^{34}$ reported a patient who experienced gastrointestinal bleeding after receiving steroids for 5 days. However, a single dose of Glucocorticoid, even a large one, can be used without a harmful effect. In our study with single dose administration of steroids, we did not notice any side effects of steroid usage.

Our study had certain limitations. The sample size was small. It had only 34 patients, who were divided into three groups. A wide range of craniofaciomaxillary procedures were included. Some of these procedures involved soft tissue and bony manipulations while others consisted only of soft tissue manipulations. The measurement of forehead oedema may not be very accurate, because of use of micropore in some patients with cranioplasty.

Further studies with larger sample size, in patients undergoing a single procedure, operated by a single surgeon are needed to establish or refute the role of steroids in reduction of postoperative facial oedema.

\section{CONCLUSIONS AND SUMMARY}

A prospective double blind study conducted to evaluate the role of Dexamethasone $8 \mathrm{mg}$ intravenous administration and Triamcinolone $0.7 \mathrm{mg} / \mathrm{kg}$ administration at the end of procedure, in reduction of postoperative facial oedema in craniofaciomaxillary surgeries. Thirty-four consecutive patients were included in the study. A log book was prepared that randomized the 34 patients to Dexamethasone, Triamcinolone administration and control group. Facial size was measured on POD1, POD2 and POD3. Facial oedema scores were derived from comparison of photographs on admission and 48 hrs. postoperatively. Findings were tabulated and statistically analysed.

\section{Following Observations Were Noted}

1. Age and gender in all 3 groups was matched and not statistically different.

2. In all 3 groups, duration of surgery was matched and not statistically significant different.

3. Facial oedema score on photographs and the difference in measurements in the facial size between the day of admission and postoperative day 2 correlated.

4. The duration of surgery and postoperative facial oedema did not correlate.

5. We found that oedema was maximum in the periorbital region in all the three groups, followed by oedema on forehead, malar and mandibular regions. We also observed that there was direct correlation between forehead and periorbital oedema.

6. We observed that there was postoperative facial oedema on POD1, reached its peak on POD2 and then started declining within each group.

7. The use of steroids either intravenous $(8 \mathrm{mg}$ Dexamethasone) or local infiltration (Triamcinolone 0.7 $\mathrm{mg} / \mathrm{kg}$ ) did not significantly reduce the postoperative facial oedema in our patient when compared to the control.

\section{REFERENCES}

1. Assimes, Themistocles L, Lessard, et al. The use of perioperative corticosteroids in craniomaxillofacial surgery. Plastic \& Reconstructive Surgery 1999;103(1):313-22.

2. Schmidt JH, Caffee HH. The efficacy of methyl prednisolone in reducing flap oedema. Plastic \& Reconstructive Surgery 1990;86(6):1148-51.

3. Colen LB, Crawley WA, Buncke HJ. Effect of parenteral steroids on oedema in replanted rat legs. Plastic \& Reconstructive Surgery 1979;63(6):830-3.

4. Habal MB, Powell RD. Experimental facial oedema: treatment with methyl prednisolone. J Surg Res 1978;24(5):353-8.

5. Nordstrom REA, Nordstrom RM. The effect of corticosteroids on postoperative oedema. Plastic Reconstructive Surgery 1987;80(1):85-7.

6. Flood TR, McManners J, el-Attar A, et al. Randomized prospective study of the influence of steroids on postoperative eye opening after exploration of the orbital floor. British Journal of Oral and Maxillofacial Surgery 1999;37(4):312-5.

7. Gurlek A, Fariz A, Aydogan H, et al. Effects of high dose corticosteroids in open rhinoplasty. Journal of Plastic, Reconstructive \& Aesthetic Surgery 2009;62(5):650-5.

8. Munro IR, Boyd JB, Wainwright DJ. Effect of steroids in maxillofacial surgery. Annals of Plastic Surgery 1986;17(5):440-4.

9. Rapaport DP, Bass LS, Aston SJ. Influence of steroids on postoperative swelling after facial plasty: a prospective, randomized study. Plastic Reconstructive Surgery 1995;96(7):1547-52.

10. Owsley JQ, Weibel TJ, Adams WA. Does steroid medication reduce facial oedema following face lift surgery? A prospective, randomized study of 30 consecutive patients. Plastic Reconstructive Surgery 1996;98(1):1-6.

11. Schaberg SJ, Stuller CB, Edwards SM. Effect of methyl prednisolone on swelling after orthognathic surgery. Journal of Oral Maxillofacial Surgery 1984;42(6):356-61.

12. Habal MB. Prevention of postoperative facial oedema with steroids after facial surgery. Aesthetic Plastic Surgery 1985;9(2):69-71.

13. Barnes PJ. Anti-inflammatory actions of glucocorticoids: molecular mechanisms. Clin Sci 1998;94(6):557-72.

14. Rhen $\mathrm{T}$, Cidlowski JA. Anti-inflammatory action of glucocorticoids: new mechanisms for old drugs. N Engl J Med 2005;353(16):1711-23.

15. Pappas AL, Sukhani R, Hotaling AJ, et al. The effect of preoperative dexamethasone on the immediate and delayed postoperative morbidity in children undergoing adenotonsillectomy. Anaesth Analg 1998;87(1):57-61.

16. Aouad MT, Siddik SS, Rizk LB, et al. The effect of dexamethasone on postoperative vomiting after tonsillectomy. Anaesth Analg 2001;92(3):636-40.

17. Romundstad L, Breivik $\mathrm{H}$, Roald $\mathrm{H}$, et al. Methyl prednisolone reduces pain, emesis, and fatigue after breast augmentation surgery: a single-dose, randomized, parallel-group study with methyl prednisolone $125 \mathrm{mg}$, parecoxib $40 \mathrm{mg}$, a placebo. Anaesth Analg 2006;102(2):418-25. 
18. McKean S, Kochilas X, Kelleher R, et al. Use of intravenous steroids at induction of anaesthesia for adult tonsillectomy to reduce postoperative nausea and vomiting and pain: a double-blind randomized controlled trial. Clin Otolaryngol 2006;31(1):36-40.

19. Rich WM, Abdulhayoglu G, DiSaia PJ. Methyl prednisolone as an antiemetic during cancer chemotherapy: a pilot study. Gynaecol Oncol 1980;9(2):193-8.

20. Sagar SM. The current role of antiemetic drugs in oncology: a recent revolution in patient symptom control. Cancer Treat Rev 1991;18(2):95-135.

21. Aasboe V, Raeder JC, Groegaard B. Betamethasone reduces postoperative pain and nausea after ambulatory surgery. Anaesth Analg 1998;87(2):319-23.

22. Griffies WS, Kennedy K, Gasser C, et al. Steroids in rhinoplasty. Laryngoscope 1989;99(11):1161-4.

23. Weber CR, Griffin JM. Evaluation of dexamethasone for reducing postoperative oedema and inflammatory response after orthognathic surgery. J Oral Maxillofacial Surg 1994;52(1):35-9.

24. Kara CO, Gokalan I. Effects of single dose steroid usage on oedema, ecchymosis, and intraoperative bleeding in rhinoplasty. Plastic \& Reconstructive Surgery 1999;104(7):2213-8.

25. Neil-Dwyer JG, Evans RD, Jones BM, et al. Tumescent steroid infiltration to reduce postoperative swelling after craniofacial surgery. British Journal of Plastic Surgery 2001;54(7):565-9.

26. Kargi E, Hoşnuter M, Babucçu O, et al. Effect of steroids on oedema, ecchymosis, and intraoperative bleeding in rhinoplasty. Ann Plast Surg 2003;51(6):570-4.
27. Gurlek A, Fariz A, Aydogan H, et al. Effects of different corticosteroids on oedema and ecchymosis in open rhinoplasty. Aesthetic Plastic Surg 2006;30(2):150-4.

28. Clune JE, Greene AK, Guo CY, et al. Perioperative corticosteroid reduces hospital stay after fronto-orbital advancement. J Craniofacial Surg 2010;21(2):344-8.

29. Ettore G, Weber M, Schaaff $H$, et al. Standards for digital photography in craniomaxillofacial surgery-part1: basic views and guidelines. Journal of Craniomaxillofacial surgery 2006;34(2):65-73.

30. Neupert EA, Lee JW, Philput CB. Evaluation of dexamethasone for reduction of post-surgical sequelae of third molar removal. Journal of oral and maxillofacial surgery 1992;50(11):1178-82.

31. Guernesy LH, DeChamplain RW. Sequelae and complications of the intraoral sagittal osteotomy in the mandibular rami. oral surg 1971;32(2):176-92.

32. Schimer BP, Parker KL. Adrenocorticotropic hormone, adrenocortical steroids, and their synthetic analogs, inhibitors of the synthesis and actions of adrenocortical hormones. In: Hardman JG, Limbird EL, Molinoff PB, et al. (Eds). Goodman and Gilman's The Pharmacological Basis of Therapeutics. 9th Ed. New York: McGraw-Hill, 1996.

33. Williamson LW, Lorson EL, Osbon DB. Hypothalamicpituitary adrenal suppression after short-term dexamethasone therapy for oral surgical procedures. J Oral Surg 1980;38(1):20-8.

34. Hoffman DF, Cook TA, Quatela VC, et al. Steroids and rhinoplasty. A double-blind study. Arch Otolaryngology Head Neck Surg 1991;117(9):990-3. 